\title{
First Amendment Standards for Congressional Investigation ${ }^{\dagger}$
}

\author{
Albert M. Bendich*
}

GINCE THE end of World War II a contest of crucial significance for the $\mathcal{S}$ political freedom of Americans has been carried on between legislative committees imvestigating "un-American" activities and witnesses who, in resisting these committees, have maintained that the investigations were themselves "un-American." Neither side has been able to score a decisive victory. For a time, the committees had things pretty much their own way. In 1957 it seemed that the tide might be turning. ${ }^{1}$ Since 1959 the committees have again held the balance of power, ${ }^{2}$ but their ascendancy has been clouded by the ambiguity of the constitutional doctrine which the Supreme Court has fashioned for resolving the conflict. Not only is the doctrine indeterminate; the Court itself is closely and bitterly divided over the crucial issue: the meaning of the first amendment's prohibition of official abridgment of freedom of speech as related to compulsory interrogation in the field of political behief and association.

Four members of the Court ${ }^{3}$ are apparently committed to the proposition that this sort of interrogation is a violation of the first amendment, and that no circumstances could justify such a violation while the amendment stands. ${ }^{4}$ Prior to the retirement of Justices Whittaker and Frankfurter last year, five Justices ${ }^{5}$ were apparently committed to the proposition that an accommodation between the coinpeting demands of liberty and security could be judicially made on a case-by-case basis through application of a "balancing" test. Under this test the first amendment is understood to protect witnesses unless the importance of extracting information from them can be said to be so "compelling" as to justify subordination of the first amendment. ${ }^{6}$

† Originally published in 1 Law CoMnTentary 40 (Spring 1963), by the California Commission on Law and Social Action of the American Jewish Congress.

* Member, California Bar; Lecturer in Speech, University of Cahfornia, Berkeley.

1 See Watkins v. United States, 354 U.S. 178 (1957).

${ }^{2}$ See Barenblatt v. United States, 360 U.S. 109 (1959).

${ }^{3}$ Chief Justice Warren, and Justices Black, Douglas, and Brennan.

4 "Four meinbers of this Court adhere to the view they expressed in Sweezy v. New Hainpshire, 354 U.S. 234, 251, and 'do not now conceive of any circumstances wherein a state interest would justify infringenıent of rights in these fields." " Scull v. Virginia, 359 U.S. 344, 353 n.7 (1959).

5 Justices Frankfurter, Clark, Harlan, Whittaker, and Stewart.

6 Barenblatt v. United States, 360 U.S. 109 (1959). 
It is the purpose of this article to demonstrate that at present there are no satisfactory or even reasonable standards by which the powers of the committees or the rights of witnesses can be assessed constitutionally and that, as a consequence, it is imperative that the controlling precedents be carefully reconsidered. In order to understand the problems in this field concretely and in their true dimensions, it may be helpful to focus upon a case so bizarre in its facts that it extends the prevailing concepts in this field to their logical extremes. To that end, the case of Shelton $v$. United States $^{7}$ has been deliberately selected.

I

\section{THE FACTUAL FRAMEWORK}

On November 14, 1955, an agent of the Senate Internal Security Subcommittee appeared at the offices of the New York Times with thirty subpoenas for Times employees. One of the subpoenas was addressed to Willard Shelton. No such person worked for the Times. ${ }^{8}$

The agent was informed that several persons named Shelton worked for the Times, but that none of them was named Willard and that the only Shelton in either the news or editorial departments had the Christian name, Robert. $^{9}$

"Well," said subcommittee chairman James Eastland, upon hearing this, "go ahead and tell him to come."10 On instructions from subcommittee counsel Sourwine, the agent wrote the words "or Robert Shelton" on the subpoena addressed to Willard, and served it on Robert. ${ }^{11}$

Three weeks later, on December 7, 1955, pursuant to subpoena, Robert Shelton, and other members of the New York press, appeared at an executive session of the subcommittee held in New York. When Shelton asked why he had been called, he was told that the subcommittee wanted to clear up a question of "identity."12

Counsel Sourwine proceeded to ask the usual questions, including the standard inquiry as to membership in the Communist Party. Shelton immediately announced that he would refuse to answer all questions touching political matters, on first amendment grounds, especially freedom of the press, since he was a newspaperman. ${ }^{13}$

${ }^{7} 148$ F. Supp. 926 (D.D.C. 1957), afj'd, 280 F.2d 701 (D.C. Cir. 1960), rev'd, 369 U.S. 749 (1962).

8 Record, pp. 49, 106, 119-24, 127-29, Shelton v. United States, supra note 7. Citations to the record were gleaned from the briefs for petitioner and for the United States.

9 Ibid.

${ }^{10} I d$. at 105-06.

11 Id. at 106, 121.

12 Id. at 52 .

13 Id at 52-55. 
Apparently, Shelton's response was unexpected, for counsel Sourwine stated that it "greatly surprised"14 him. "The record will show," he continued, "that the witness was not charged with being a Communist. Counsel said you are not a Communist and you never have been; isn't that right?"15 he asked.

Shelton, however, remained adamant; he would not answer political questions; he would not affirm that he was, indeed, patriotic. Thereby, he refused to honor the implication in the questions that there was any ground to suppose he was not patriotic; that Americans carry the burden of proving their mnocence of possible disloyalty; and that the subcommittee was pursuing a proper course in playing the role of political confessor.

Stymied for the moment, Sourwine announced that the subcommittee might have to investigate the case further. A month later, on January 4, 5 , and 6,1956 , the subcommittee held public hearings in Washington, D.C., and recalled Robert Shelton. ${ }^{16}$

Senator Eastland made a brief opening statement explaining that the investigation was of great importance because "the international Communist conspiracy has as one of its primary aims the influencing of public opmion ...." and announcing that the hearings would constitute a "subsequent chapter to the Burdett testimony ...."17 Winston Burdett, a broadcaster and newspaperman, had testified about his membership in the Communist Party from 1937 to 1942 at hearings held by the subcommittee on June 28 and 29, 1955. ${ }^{18}$ Burdett had performed what the subcommittee called the "patriotic service" of nanning all former associates whom he could recall as having been party members from thirteen to eighteen years earlier. Yet none of the persons so named was linked by Burdett with any "conspiratorial" effort of "influencing public opinion."19 Moreover, the record shows that at no point in his testimony did Burdett mention any person named Shelton. ${ }^{20}$

"I fail to see," Shelton protested, "why I am involved in this hearing .... There was no reference to me in the Burdett testimony ...."21 The subcommittee, he insisted, had no jurisdiction to compel "a victim of accident" to testify about his beliefs, opinions, and political associations. ${ }^{22}$

\section{Id. at 56-57.}

15 Ibid.

$10 I d$. at $70-71$.

17 Id. at 71 .

18 Ibid.; see Hearings Before the Subcommittee to Investigate the Administration of the Internal Security Act and other Internal Security Laws of the Senate Committee on the Judiciary: Strategy and Tactics of World Commumism [hereinafter cited as Hearings] (pt. 14), 84th Cong., 1st Sess. 1324-63 (1955).

19 Hearings (pt. 14), at 1324-63.

$20 \mathrm{Ibid}$.

${ }^{21}$ Record, p. 84 .

22 Id. at 87 . 
Nevertheless, Shelton was sworn and interrogated a second time. As before, he steadfastly refused to answer all questions dealing with political beliefs or associations. ${ }^{23}$ Therefore, he was indicted for the crime of contempt of Congress, ${ }^{24}$ and his conviction by a federal district court ${ }^{25}$ was affirmed by the Court of Appeals for the District of Columbia. ${ }^{26}$ Last June, the Supreme Court reversed his conviction on the narrow ground that the indictment had been inadequate, since it had failed to specify the subject under inquiry at the time of his alleged contempt. ${ }^{27}$ This ruling, of course, allowed the Government to reindict, this time including the necessary specification. The new indictment was returned by a federal grand jury on October 1, 1962, ${ }^{28}$ and on February 14, 1963, he was again found guilty of contempt of Congress by a federal district court. ${ }^{20}$

\section{II}

\section{THE LEGAL BACKGROUND}

For more than a decade, the Supreme Court refused to come to grips with the first amendment problem in this area, although repeatedly requested to do so from 1947 on. ${ }^{30}$ Yet these were years of clash and crisis, years which witnessed the jailing of the "Hollywood Ten," the rise of McCarthyism, and the institutionalization of blacklists in the mass media, based largely upon the dossiers compiled by the investigating committees. ${ }^{31}$ During these years, the lower federal courts upheld the powers and practices of the investigators against all first amendment challenges. In 1957, however, in its well known Watkins decision, the Court declared unequivocally that congressional investigations, as a part of the legislative process, were limited by the first amendment. ${ }^{32}$ This was a deceptively simple pronouncement, as was discovered by those who relied upon it in resisting committee inquiries only to suffer convictions for contempt of Congress. ${ }^{33}$ For

23 Id. at 84-96.

24 Id. at 1-2, under REV. STAT. § 102 (1875), 2 U.S.C. \$ 192 (1958).

25 United States v. Shelton, 148 F. Supp. 926 (D.D.C. 1957).

20 Shelton v. United States, 280 F.2d 701 (D.C. Cir. 1960).

27 Shelton v. United States, 369 U.S. 749 (1962).

28 San Francisco Chronicle, Oct. 2, 1962, p. 14, col. 1.

${ }^{20}$ N.Y. Times, Feb. 16, 1963, p. 8, col. 2 (Western ed.).

30 See, e.g., Lawson v. United States, 176 F.2d 49 (D.C. Cir. 1949), cert. denied, 339 U.S. 934 (1950); Barsky v. United States, 167 F.2d 241 (D.C. Cir.), cert. denied, 334 U.S. 843 (1948); Josephson v. United States, 165 F.2d 82 (2d Cir. 1947), cert. denied, 333 U.S. 838 (1948).

31 See Cogrey, Report on Blackisting (1956). See also Newsweek, June 4, 1962, p. 86. 32 Watkins v. United States, 354 U.S. 178, 188 (1957).

33 See, e.g., Hartman v. United States, 290 F.2d 460 (9th Cir. 1961), rev'd per curiam on other grounds, 370 U.S. 724 (1962) ; Braden v. United States, 365 U.S. 431 (1961). 
Watkins, despite its discursive and scathing historical review of political and religious inquisitions, and despite its denunciation of "exposure for exposure's sake" and the vagueness of "un-Americanism" as a standard for compulsory interrogation, failed to provide any guides concerning the nature of first amendment protection. Moreover, all the constitutional language in Watkins was dictum, since its actual holding was limited to the nonconstitutional issue of pertinency. As a result, the first amendment question remained virtually as unilluminated after Watkins as it had been before it. Another two years were to pass before the Court undertook to decide the question: to what extent and in what ways does the first amendment protect persons against punishment for refusing to furnish legislative investigating committees infornation concerning their political beliefs and associations.

In 1959, in Barenblatt v. United States, ${ }^{34}$ the Court, by a five-to-four decision, appeared to write a blank check for legislative investigation of "communism." Lloyd Barenblatt had been identified by a former friend and schoolmate as having been a member of a Communist discussion group at the University of Michigan. The group, according to the informer, was composed of a few graduate students and junior faculty members, and was interested mainly in intellectual and doctrinal matters, rather than action. An area of particular interest for the group was said to be the relation of Marxism to esthetic theory. Barenblatt's refusal to confirm or deny this story was held to have deprived the investigators of information for which they had a "compelling need"; this information was held so vital to our survival that the subordination of the first amendment's protection, which he would otherwise have enjoyed, was justified..$^{35}$

On their face, these facts hardly seem to justify a finding of "compelling need." How, then, is the Supreme Court's decision to be explained? As we shall see, the decision is ambiguous and, mdeed, contradictory; it may not be possible, therefore, to "explain" it in the sense of making it appear to be reasonable. But before we undertake an analysis of its internal logic, there are a few clues to the majority's approach which may clear up some preliminary difficulties.

Barenblatt's basic first amendment argument was that compulsory inquiry into political or intellectual belief and association is absolutely barred, and that it can never be justified by any facts or circumstances so long as the amendment stands. The majority of the Court rejected this view as unrealistically "absolutistic." This much is clear. What is unclear is the nature of the test to be used to distinguish between those situations where the amendment's protection will prevail and those where it will be 
subordinated to overbalancing interests. The Court enunciated the test in these words: "Where First Amendment rights are asserted to bar governmental interrogation, resolution of the issue always involves a balancing by the courts of the competing private and public interests at stake in the particular circumstances shown." ${ }^{, 36}$ But what were the competing interests in Barenblatt? The majority spoke of them as personal privacy, on the one hand, and national survival, on the other ${ }^{37} \mathrm{It}$ is perhaps possible to "weigh" these values, though the competence of courts in this area seems most dubious. ${ }^{38}$ If they are to be weighed against each other, however, it would seem to be a prerequisite to establish the precise factual relation between the two. What is the relation between the information withheld by Barenblatt and our survival? The answer turns, of necessity, on the theory according to which survival is or is not threatened. Since no such theory was stated by the majority, it is. difficult to know how or what to balance.

If the majority's theory was that communism is inherently dangerous, whether in small or large amounts, like some viruses, so as to justify subordination of the first amendment whenever inquiry concerning it is made, the only way Barenblatt could have challenged his conviction would have been to make a factual showing at his trial that communism had ceased to exist at the time of his interrogation, or that its nature had changed so that it was no longer "dangerous." On this view, since he made no such challenge, this defense was waived and he was properly convicted.

On the other hand, if the inajority's theory was that Communist activities might constitute a danger to survival, "in the particular circumstances shown," Barenblatt might have challenged his conviction by showing that in his case the facts and the circumstances could not warrant an inference of danger. On this view, since he made no attempt to make such a showing, this defense was waived, and his conviction was proper. ${ }^{39}$

In fact, Barenblatt argued that under no circumstances could his interrogation be justified in the face of the first amendment. From this viewpoint, it was, of course, irrelevant to go into the facts. But, in answer to the abstract argument that it is never constitutionally permissible to compel disclosure of political belief and association, the majority found it sufficient to say that sometimes it is.

Although the majority's answer may be justified in the premises of the

36 Id. at 126.

37 For a different formulation of the factors to be balanced see id. at 144-45 (Black, J., dissenting).

38 See Dennis v. United States, 341 U.S. 494, 525, 551-52 (1951) (Frankfurter, J., concurring).

${ }^{39}$ Cf. Whitney v. Cahfornia, 274 U.S. 357, 379 (1927) (Brandeis, J., concurring): "Whether ... there was in California such clear and present danger of serious evil, might have been made the inportant issue in the case." 
issues as framed in Barenblatt, it can hardly be of assistance to witnesses, courts, or committees when the question is whether facts and circumstances are of such a character as to warrant subordination of the first amendment. If it is assumed that the first amendment can correctly be subordinated when the need to do so is compelling, what are the guides for determining whether such a need exists? Is there some clue to this problem in Barenblatt? Or was Justice Black correct in stating in his dissent that the balancing test meant that the protection afforded by the first amendment was whatever five justices on the high court thought it ought to be? ${ }^{40}$

According to the majority, the House Un-American Activities Committee possessed "pervasive" authority to make such investigations. ${ }^{41}$ This might be taken as an endorsement of the proposition that communism is a sufficient threat to our survival to justify investigations in the face of the first amendment in every case. On the other hand, the words in the balancing test to the effect that resolution of the first amendment issue requires appraisal of the competing interests "in the particular circumstances shown" ${ }^{\prime 2}$ might be taken as indicating that the courts would have to balance anew the interests in each case. That the former meaning was intended may be inferred from the majority's statement that the congressional right of investigation in aid of its "wide power to legislate in the field of Communist activity in this Country . . . is hardly debatable." 43 "In the last analysis," said the inajority, "this power rests on the right of self-preservation, "the ultimate value of any society." "\$44 To be sure, it is difficult, if not impossible, to conceive of an ultimate value being overbalanced by a necessarily lesser value. Yet the ultimate value could not be placed in the judicial scales unless a factual demonstration of a serious threat to national survival could be shown. Anything less would presumably not involve the issue of survival, unless it could be argued logically that nonserious threats raise the issue of self-preservation. This analysis iniplies that it is the latter meaning-that balancing must be done in each case anew-that was intended. Further support for this construction may lie in the majority's statement that the "power and right of resistance" to congressional inquiry "are to be judged in the concrete, not on the basis of abstractions." 45 Surely the question of self-preservation is not one to be answered on the basis of abstractions. Hence, it would appear that whether, in a given case, a demand for specific information is so related to survival as to compel

\footnotetext{
40360 U.S. at 143.

41 Id. at 118.

42 Id. at 126.

43 Id. at 127.

44 Id. at 127-28.

$45 \mathrm{Id}$. at 112 .
} 
subordination of the first amendment protection must be decided on the concrete basis of the particular facts and circumstances involved.

Assuming, therefore, that a factual assessment of the interests to be balanced must be made in each case, what is the standard that courts must apply in determiming whether self-preservation is sufficiently involved that the ultimacy of its importance may be vindicated? Here Barenblatt offers no assistance beyond the cryptic remark that the subordinating interest of the state must be "compelling."

Barenblatt challenged the legitimacy of the general question, "Are you a member of the Communist Party?" on the theory that it failed to focus on activities that might be said to relate to issues of proper congressional concern, such as national defense or protection against espionage and other threats to self-preservation. For it is clear, as the majority opinion conceded, that among other things communism covers areas of activity in no way related to such matters. The majority, nevertheless, brushed this objection aside on the theory that "the investigatory process must proceed step by step" and that an "investigation of advocacy of or preparation for overthrow certainly embraces the right to identify a witness as a member of the Communist Party." an investigation is labelled "an investigation of advocacy of or preparation for overthrow" that the persons being investigated are properly so labelled. Further, it does not follow that such advocacy or preparation will necessarily threaten our survival to the degree that our need for extracting information concerming such activities can be deemed compelling. However, these are questions which Barenblatt failed to raise because his strategy of fighting the case on abstract principles ruled them out as factual. But there is still an issue of great importance which can be dealt with logically on the basis of the principles involved. That issue has to do with the contradiction between the "identification theory" and the "compelling need" theory.

If a witness is suspected of having information relating to activities aimed at overthrow, why is it necessary to inquire first as to whether he is a Communist? Why not ask the direct questions: "Are you now or have you ever been engaged in activities aimed at overthrow?"48 "Do you know any persons who have?" If affirmative answers are given, it is then possible to ask for the organizational source or basis, if any, for these activities. The answer might or might not cite the Communist Party. But if the answers to the initial questions are negative, there is no reason at all for asking the organizational question. If investigation must proceed "step by 
step," then first steps should come first. The implication in asking the membership question first is that there is no basis for asking the witness questions about specific activities. Instead, a fishing expedition is implied, following the general pattern: "Tell us whether you are a member and, if so, who else is and what you do." The majority's approach can be squared with the compelling need theory only on the assumption that, no matter what the surrounding facts and circumstances, self-preservation demands identification of all Communists. This constitutes a paradoxical reversal of Barenblatt's absolutist position, for the Court seems to have embraced the equally "absolutistic" position that, regardless of the facts, the compulsion to answer the question, "Are you a Communist?" is never barred by the first amendment.

The Court, however, cannot have it both ways. Either balancing is to be done case by case on the basis of the facts, or it is to be done once for all on the basis of abstract principles. If our analysis is correct in assuming that the compelling need theory requires a case-by-case approach, it follows that every investigation must have independent justification. Moreover, an investigation cannot be justified only by what it turns up; rather, what may turn up-including a refusal to testify-must find its justification in a prior showing of compelling need. If the only information demanded of a witness, or if the only information he can reasonably be expected to furnish, relates to Communist activities that are not connected with self-preservation, either because of their innocuous character or by virtue of their being neutralized by legislation already enacted, there can be no basis for asserting a compelling need. Thus, the general question, "Are you a Communist?" cannot be said to be justified by the compelling need theory, unless the proper foundation has been laid for asking it. For on this analysis, there could never be a compelling need to legislate against a nonexistent threat; and to identify a Communist in order to find out whether there is a threat in his activities is to beg the question of compelling need. A proper foundation would have to show that the information being demanded could be reasonably thought to be in the witness' possession, and also that it seriously relates to self-preservation in a way not already covered by existing legislation. As matters stand, however, the law seems to be that the identification question is a permissible first step.

At the conclusion of its opinion, and almost as an afterthought, the majority listed two other criteria to be followed by courts in adjudicating first amendment claims: that there is no right to pillory witnesses, ${ }^{49}$ and that they may not be punished for refusing to answer questions if their appearance is due to "indiscriminate dragnet procedures, lacking in probable cause" for belief that they possess information which might be help- 
ful to the investigation..$^{50}$ The only clue to the meaning of probable cause in the majority's opinion is that Barenblatt was identified as a former Communist, under oath, by the informer who preceded him to the stand. But whether such identification is necessary to a finding of probable cause was not made clear. The majority did not say whether some other form of identification might suffice.

Two years after the decision in Barenblatt, the Supreme Court decided two other cases dealing with these issues, Wilkinson $v$. United States ${ }^{61}$ and Braden v. United States. ${ }^{52}$ However, these decisions added nothing to what was said in Barenblatt. Wilkinson and Braden followed the same strategic course which had been set by Barenblatt in relying exclusively on principle and eschewing factual analysis. Consequently, in holding that there was a compelling need for the information demanded from Wilkinson and Braden, the Court merely cited its decision in Barenblatt. The issue of probable cause was similarly treated. Since Barenblatt, Wilkinson, and Braden are the only cases dealing with the first amendment aspects of congressional inquiry into "un-Americanism" which the Supreme Court has decided since its 1957 Watkins decision, the meaning of the compelling need and probable cause concepts necessarily remains vague.

\section{III}

PROBABLE CAUSE AND THE Shelton CASE

Whereas Barenblatt, Wilkinson, and Braden had been identified under oath before their interrogators as Communists, Robert Shelton had never been so identified. Indeed, the manner of his "identification" is so curious that it must be detailed carefully before it can be understood.

It will be recalled that subcommittee counsel Sourwine had stated, at the 1955 executive session hearings, that Shelton was not being charged with Communist associations..$^{53}$ At Shelton's contempt trial, however, Sourwine altered his course and testified that he could recall having received information prior to the 1955 hearings purportedly connecting a "Shelton" (no first name) on the New York Times staff with a Communist group on that newspaper. ${ }^{54}$ This information, Sourwine continued, was contained in a letter from a reliable informant, signed with a pseudonym..$^{\text {t5 }}$ Nevertheless, Sourwine could not explam why he should have claimed to

50 Ibid.

51365 U.S. 399 (1961).

52365 U.S. 431 (1961).

53 See text accompanying note 15 supra.

54 Record, pp. 48-49.

65 Id. at 98 . 
be surprised when Shelton refused to "co-operate" with the subcommittee at the executive session if he had had such a letter. ${ }^{58} \mathrm{He}$ was also unable to explain why the name "Willard" should have been used on the subpoena, since no such person was connected with the Times. ${ }^{57}$ Under crossexamination, Sourwine revealed that neither he nor the subcommittee members knew the identity of the informant he had characterized as "reliable," and that he based this characterization on what he took to be a resemblance between the alleged "typing" and general "tone" of the Shelton letter and that of other pseudonymous letters previously found to have been "reliable." Though he admitted that the Shelton letter contained fifteen to eighteen names of other persons, the only name he could recall was "Shelton." ${ }^{\circ 0}$ When pressed further, Sourwine concluded: "I have no actual independent memory of this particular letter as a sheet of paper and what was on it."

At his first trial, Shelton had subpoenaed the subcommittee's records to prove that they contained no information relating to himself, but the subpoenas were quashed on the Government's motion. ${ }^{22}$ The Government also successfully opposed his repeated demands at that trial for the production of the pseudonymous letter, ${ }^{63}$ thus preventing the testing of his claim that this would prove that the Government could not produce the letter because it didn't exist, and that the Government's "probable cause" argument was a fabrication. Sourwine's asserted ground for refusing to produce the letter was that it was "confidential."

In the Government's view, therefore, it seems that the requirement of "probable cause" may be satisfied when an anonymous informant deemed "reliable" by a committee identifies a witness in an unsworn letter which need not be produced in court if the committee deems it "confidential." This, of course, is a claim that need only be asserted to prevail, since it defies challenge. On this view, how substantial is the Supreme Court's guar-

56 Id. at 112 .

57 Id. at $102-03$.

68 Id. at 100-01.

50 Id. at 102. "Pseudonym" in this context imphes a name obviously fictitious, such as "Brown-eyes"; otherwise, since Sourwine clained not to know the alleged informer's identity, he could not have assumed the name to be a pseudonym. Yet, it developed from Sourwine's testimony at the second Shelton trial, that the naine of the informer was Finbar, which is not obviously pseudonymous. The paradox may never be cleared up, however, inasmuch as Sourwine also testified at the second trial that he had destroyed the letter while Shelton was pending in the Court of Appeals for the District of Columbia. See I.F. Stone's Bi-Weekly, Feb. 18, 1963, p. 6 .

60 Record, pp. 172, 185-88, 189-90, 196.

61 Id. at 186.

62 Id. at $25-39$.

03 Id. at $99,11 \%, 169,181$.

64 Id. at $118,212$. 
antee that dragnet proceedings lacking in probable cause will not be countenanced in first amendment investigations?

What is truly sobering is that the Government, as represented successively by the subcommittee, the Senate, the United States attorney, a federal grand jury, a federal district court, a court of appeals, and finallyshort of the Supreme Court itself ${ }^{65}$-by the Solicitor General's office, has seen nothing constitutionally infirm in all this, notwithstanding the probable cause guarantees of the Barenblatt, Wilkinson, and Braden decisions.

\section{IV}

\section{THE GOVERNMENT'S THEORY OF PROBABLE CAUSE}

It has long been clear that there are several concepts of probable cause, and that the phrase has different meamings, requiring the application of different standards, depending upon the subject in question. Thus, for example, the probable cause test in the field of commercial regulation ${ }^{06}$ is qualitatively different from the probable cause test in criminal cases. ${ }^{07}$ Since the phrase is not self-defining, and since it had never been coupled with a first amendment investigation prior to Barenblatt, it was far from evident whether the Court meant to imply that one of the existing ineanings of the phrase was to be used and, if so, which one was intended, or whether it was to be given a new and different meaning. It is clear, however, that the meaning which is attributed to probable cause in the field of political investigations will affect the scope and content of first amendment protection. ${ }^{67 a}$ The meaning which is selected must therefore inevitably reflect basic attitudes toward freedom of speech.

The meaning selected by the Government in Shelton reflects a new and dangerous attitude. The United States attorney who prosecuted Shelton made the following argument at the first trial: "[A] man off the street

65 In Shelton v. United States, 369 U.S. 749 (1962), the Court did not reach the issue of probable cause. However, Justice Harlan, in a dissent in which Justice Clark joined, was of the opinion that the probable cause requirement had been satisfied. Id. at 781 .

66 See, e.g., United States v. Morton Salt Co., 338 U.S. 632 (1950) ; Oklahoma Press Publishing Co. v. Walling, 327 U.S. 186 (1946); 1 Davis, Aoministrative Law Treatise 231-32 (1958).

67 See, e.g., Draper v. United States, 358 U.S. 307 (1959); Carroll v. United States, 267 U.S. 132 (1925).

67a In Marcus v. Search Warrant, 367 U.S. 717, 724 (1961), the Supreme Court noted that "historically the struggle for freedom of speech and press in England was bound up with the issue of the scope of the search and seizure power." "This history," the Court pointed out, "was, of course, part of the intellectual matrix within which our own constitutional fabric was shaped. The Bill of Rights was fashioned against the background of knowledge that unrestricted power of search and seizure could also be an instrument for stifling liberty of expression." Id. at 729. 
could be called off the street and asked, 'Are you one of the persons that we have a duty to protect the country from?" " The philosophy reflected in this statement is clearly incompatible with the "compelling need" requirement, to say nothing about the presumption of innocence ${ }^{69}$ and the right of privacy. Of course, this statement was made prior to the Court's decision in Barenblatt. But the Solicitor General made substantially the same argument in his brief to the Supreme Court in Shelton, long after Barenblatt, Wilkinson, and Braden had been decided. His brief argues that even if there were no reasonable basis for thinking that Shelton had any information about communism, he could at least clarify for the subcommittee whether he was the Shelton identified by the informant. ${ }^{70}$ The theoretical underpinning provided for this argument is frankly stated to rest on the contention that probable cause standards in the field of commercial regulation ought to govern investigations into "un-Americanism."71

This is a dismaying and startling theory, presupposing equal constitutional authority to conduct an investigation into a subject like wages and hours in interstate commerce, on the one hand, and into political beliefs and associations of private citizens, on the other. But while Congress has plenary power over interstate commerce and may investigate that area merely because it is suspicious or even curious, no one has ever suggested that Congress has similar powers in the area of first amendment freedoms. Here, congressional power has been considered to be nonexistent, or conditional upon a prior showing of clear and present danger, or, at the very least, even under the Court's balancing test, not subject to compulsory investigation in the absence of "compelling need."

The Government's position implies that there ought to be less protection for persons exercising the supposedly sacred freedoms guaranteed by the first amendinent than for persons suspected of criminal activity. It also

68 Record, p. 40.

69 Compare Speiser v. Randall, 357 U.S. 513 (1958).

70 Brief for the United States, p. 61.

71 Compare the Supreme Court's statement in Marcus v. Search Warrant, 367 U.S. 717, 730 (1961):

[A] State may not impose absolute criminal liability on a bookseller for the possession of obscene material, even if it may dispense with the element of scienter in dealing with such evils as impure food and drugs. [In Smith v. Califorma, 361 U.S. 147, 152-53 (1959)] we remarked the distinction between the cases: "There is no specific constitutional inhibition against making the distributors of food the strictest censors of their merchandise, but the constitutional guarantees of the freedom of speech and of the press stand in the way of imposing a similar requirement on the bookseller."

Obscene speech, the Court continued, though beyond the scope of first amendment protection, nevertheless could not be treated as if it were ordinary contraband. It would seem, therefore, that speech concededly within the scope of first amendenent protection, such as Barenblatt's, should have at least as much protection as obscene speech against being assimilated to commercial evils. 
implies that the Court's use of the phrase "probable cause" in Barenblatt, Witkinson, and Braden was no more than an empty, if not cynical, bit of rhetoric; that, in other words, the phrase is meaningless. If, in the Government's view, the protection of probable cause is tantamount to no protection, what sort of protection does the compelling need test provide?

Before the Government's arguments in Shelton, it had appeared that, upon a proper challenge, factual evidence of compelling need might have to be presented before a court could hold a defendant's first amendment protection overbalanced by the importance of the demand for information. It had appeared also that, if there were no probable cause for supposing that a witness could provide the information being sought, there could a fortiori be no compelling need to secure it from him. Yet, despite the fact that the record in Shelton provides factual evidence which negates both probable cause and compelling need, the Government has insisted on his conviction.

The evidence which negates compelling need in Shelton can be found in subcommittee member Hennings' description of the purpose of the hearings that resulted in Shelton's conviction. Their purpose was said to be to discover the "extent and nature of so-called Communist infiltration, if such exists, mto any news dispensing agency.... [and] to show such participation and sucli attempts as may be disclosed ... to influence or to subvert the American Press:"72 Further, Senator Hennings said: "[W] have no list of prospective witnesses, nor has any offer of proof as to what their testimony is likely to be been given to this subcommittee . ..."73 These statements clearly imply that what was being sought was evidence of a situation which there was no reason to think existed at all. Surely, there can

72 Record, pp. 72-73. (Emphasis added.) At Shelton's second trial, Senator Eastland responded as follows under cross-examination:

Q. Senator, what legislation was under consideration by the subcommittec at the time you called the witnesses from the New York Tines in executive and public session?

A. Well, it was a study of Cominunist infiltration and control of mass media of colnmunications and these hearings were Communist infiltration in the press, newspapers, these particular hearings ... we were seeing, first, if there had been infiltration; second, the extent of it. If we found these two things; tbird, what we could do about it. . . .

Q. I repeat my question. What legislation did you have under consideration at this time?

A. Well, I have said we had no legislation. We had no bills pending that I recall. ...

Q. . . Can you remember any legislation that was even suggested, if not pending, to which this might be relevant?

A. No, sir. As I said, as I recall, it was a study to see what we could do, the Constitution of the United States being what it is, and we first had to find out what the problem was.

Quoted in I.F. Stone's Bi-Weekly, Feb. 18, 1963, p.6.

73 Record, p. 76. 
be no compelling need to obtain such evidence; nor can there be probable cause to expect a witness to provide infornation when there is no reason to believe it exists. If probable cause and compelling need are necessary conditions of the subordination of first amendment protection, the Shelton hearings cannot be justified on the theory that they might have produced information which could later be said to have been important.

The opposite view rests on the sort of logic which, in answer to the contention that a search is invalid without probable cause, replies that the search is justified by what it turns up; and it is a constitutional commonplace that, in the area of crime, search cannot be so justified. ${ }^{74}$ But the logic of the Government in Shelton goes even further and asserts that the search is justified not only when it discloses reason for concern but also when it turns up evidence of innocence. This position makes sense only on the assumption that searches are totally self-justifying. But this would require that coinpelling need and probable cause be understood to mean precisely the opposite of what they suggest. A contrary position would require us to assume that probable cause and compelling need exist to determine whether probable cause and compelling need exist.

It is possible to make out a similar case in Barenblatt, though it is not quite as strong. The purpose of those hearings was described as follows: "The objective of this investigation is to ascertain the character, extent and objects of Communist Party activities. .. ."76 In Shelton it is clear, and in Barenblatt it can be inferred, that the first amendment was subordinated to see whether there was justification for doing so. Indeed, the record in Shelton requires even more extreme conclusions, for if subcommittee counsel Sourwine spoke the truth when he told Shelton he was not charged with Communist associations, and if the Solicitor General meant what he said in asserting that Shelton was obligated to clear up the identity question even on the assumption that there was no reasonable ground for believing him to have Communist associations, ${ }^{76}$ then we must assume that in their view compelling need exists to disconfirm what is not seriously believed. On this view, evidence of compelling need is wholly irrelevant.

If this is the correct view, if it is to be the law, then honesty requires that we stop speaking of "compelling need" and "probable cause" and speak, instead, of "curiosity" as the sole precondition for subordinating the first ainendment.

74 Johnson v. United States, 333 U.S. 10 (1948). Moreover, it is clear in the field of criminal law, at least, that the fruits of an illegal search or seizure nuay not be rehed upon as probable cause for a subsequent search or seizure. Nardone v. United States, 308 U.S. 338 (1939).

75 Barenblatt v. United States, 360 U.S. 109, 130 n.31 (1959).

${ }^{6}$ See note 70 supra and accompanying text. 
SUBVERSION OF THE PRESS-ILLUSION OR REALITY?

The Government's part in Shelton gives one the impression that it was conceived by Lewis Carroll or, better, Franz Kafka. Consider the following facts. The hearings were said to be concerned with Communist infiltration of the press as a means of influencing public opinion. But the hearings had no direct concern with the subject of influencing public opinion, since no interest was shown in the content of the newspapers involved. If the object of the hearings was to gather evidence for possible remedial legislation, was it not necessary to have some notion of what to remedy and how? Does this not require some attention to the content of the papers being investigated? How, for example, can it be determined that remedial legislation is required if it is not shown that Communist propaganda exists in newspapers? Senator Hennings seemed to be somewhat aware of this problem. "I think," he said at the hearings, ". . that it should be clear that the best evidence of any subversion or infiltration into any news-dispensing agency or opinion-forming journal is certainly the product itself."77 But, he also added that "at some later time, perhaps, it might be appropriate for executives of some of the newspapers under inquiry, whose employees are under inquiry, to be called and to testify and for them to show, if they can show, that the end product, the newspaper itself, has not been influenced by these efforts."78 Thus, as with Shelton, the burden of proof was placed upon publishers, themselves entirely beyond suspicion. On this view, all of us who are immocent of any "subversive" intent or belief can be compelled to prove that we are so upon pain of being jailed for contempt. Senator Eastland applauded this statement, saying, "The Chair thinks that is a very fine and very accurate statement, one with which the Chair certainly agrees, in its entirety."79 Of course, there never was any follow-up on content.

Moreover, the record of the hearings contains much evidence actually refuting the assumption that Commumists may have attempted to influence the press or that it could be done, given the desire to accomplish it. First, not one of the witnesses who appeared, including many co-operative witnesses who were former Communists, alleged that attempts to influence the content of the press were ever made. Even Winston Burdett, whose testimony triggered the hearings, according to chairman Eastland, gave

77 Quoted by Justice Douglas in Shelton v. United States, 369 U.S. 749, 773 (1962) (concurring opinion).

78 Id. at 774 .

79 Ibid. 
no such testimony. ${ }^{80}$ To the contrary, Clayton Knowles, a New York Times reporter who admitted having been a Communist, stated: "I can tell you nothing, gentlemen, of intrigue or conspiracy." Knowles: "Have you ever been told to slant stories one way or the other?" and was answered: "Never on the Times nor on any other paper." 82 Seymour Peck, another Times man, also admitted to past Communist membership, but refused to name associates because "none . . . contributed in any way to a conspiracy or to a menace to our institutions." ${ }^{83}$ Alden Whitman of the Times, who admitted past inembership and refused to inform on others, based that refusal on the ground that he had engaged only in lawful political activity, entirely unconnected with overthrow of the Government. $^{84}$

Further, there is no sound theoretical basis for supposing that the press could be "subverted" by Communist reporters using "un-American" perspectives to "slant" their work. As Dan Mahoney, a reporter for the New York Mirror for twenty-two years, said:

I have never slanted a news story or distorted a news event. The work of any newspaperman daily passes the closest scrutiny of his editors.... After stories are in print, they are compared to competition papers' coverage of the same news event. It would be apparent immediately if a newspaperman was slanting his writing. ${ }^{85}$

To this there are two possible answers. First, it might be argued that the theory would not hold if all papers were controlled by Commumists. But, if that were the case, the possibility of conducting hearings of this character would be slight, and little reason would exist for any "slanting" to continue; so the assumption is really not relevant. Second, it might be said that the propaganda, although too subtle to be detected, ${ }^{86}$ is nevertheless dangerous. Since it cannot be detected, there is no purpose in attempting to do so. Instead, Communists can be detected and, on the assumption that they do what they cannot be proven to do, it is reasonable to isolate and blacklist them. Of course, there can be no effective answer to this argument, since it is impossible to refute a nontestable assimption. In any event, why worry about undetectable propaganda? Could anything be more useless or self-contradictory? Moreover, if anyone is clever enough

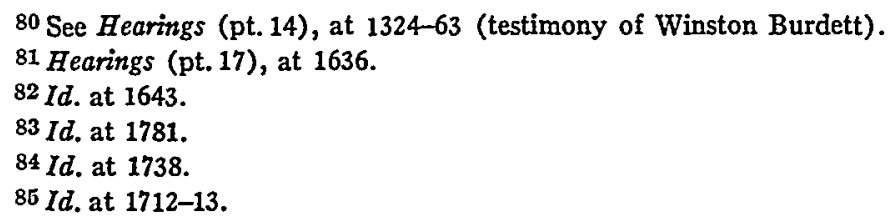

80 See Hearings (pt. 14), at 1324-63 (testimony of Winston Burdett).

81 Hearings (pt. 17), at 1636.

82 Id. at 1643 .

83 Id. at 1781.

$84 I d$. at 1738.

85 Id. at 1712-13.

80 This is an attitude which is so pervasive that it even finds expression in formal legal enactinents. See, e.g., CaL. Educ. Code \$ 12951(e) ("Dilworth Act"); N.Y. Sess. Laws 1949, ch. 360 ("Feinberg Law"). 
to be able to produce such propaganda, he ought to be clever enough to avoid personal detection as well.

\section{CONCLUSION}

We may now return to the problem of standards in contempt cases. If our argument has been sound, it would seem to follow that there can be no real separation between the concepts of probable cause and compelling need. The two are inevitably interrelated. Assuming that it is constitutionally correct to subordinate the first amendment to a sufficiently compelling need, and assuming that such a need can be factually demonstrated, what can we say about its probable characteristics? Surely, there can be no compelling need to cover subjects already adequately legislated upon, and, if anything, the subject of commumism is presently overlegislated. Logically, a compelling need for further legislation in this field could be shown only by demonstrating some inadequacy in the existing legislative pattern in one or both of two ways. Either the legislative net is too loose to catch the fish it was intended for, or the net was too narrowly conceived to cover areas intended or required to be covered. In any event, the specific problem or problems must be stated and defined clearly. "Communism" as a statement of the problem is obviously too broad to serve our purposes. Extending, as it does, over areas already controlled as well as those possibly requirmg further control, it cannot serve to identify a compelling need. ${ }^{80 a}$ Nor can it serve to identify probable cause. Probable cause to summon a witness necessitates that he be reasonably expected to possess information relevant to the defined problem area. Once probable cause could be shown, a recalcitrant witness would be able to challenge the investigation on the basis of the lack of compelling need. The present use of such concepts as "communism" and its allied "identification" theory makes a mockery of the theory of constitutional standards contemplated by the balancing test and the probable cause test, since they beg the questions each was designed to help answer.

If final proof is required to show the madequacy of the framework laid down in Barenblatt for making intelligent disposition of these problems, it may be found in Justice Harlan's dissent from the Court's decision to reverse Shelton because of the inadequacy of the indictment. After arguing that the indictment was not faulty, Justice Harlan, the author of the Barenblatt opinion, turned to the constitutional issues. "On the merits," he said, "these convictions are of course squarely ruled against the peti-

86a Compare Alexander Meiklejohn's criticism of the "complex" nature of the question: "Are you now, or have you ever been, a member of the Commumist Party?" as covering areas which may be the subject of legislation as well as areas from which the first amendment excludes legislation. Meiklejohn, The Barenblatt Opinion, 27 U. CEx. L. REv. 329, 338-39 (1960). 
tioners by principles discussed in our recent decisions in the Barenblatt, Wilkinson, and Braden cases. ..."87

If Justice Harlan is correct, it is profoundly important that Barenblatt be reconsidered. But we should not rest on that. It is imperative that we rethink the Communist issue in light of the damage our present attitudes have permitted to be done to our most cherished values. It is, after all, a fact that countries such as France and Italy, where Communist parties are truly large and powerful and where they control large segments of the press, are understood by us to be full-fledged members of the "freeworld" community, trustworthy allies, and viable democracies. Is this not persuasive evidence that our overzealous efforts to maintain our "selfpreservation," as typified in the Shelton record, have been the products of nothing so much as irrational fears? In the end, it will be our ability to deal rationally with these questions that will determine whether we can preserve the first amendment's guarantee of political freedom. 